\title{
Sharpshooters, Leafhoppers, Cicadellidae (Insecta: Hemiptera: Auchenorrhyncha: Cicadellidae) ${ }^{1}$
}

Chris Tipping and Russell F. Mizell, $\mathrm{II}^{2}$

\section{Introduction}

Sharpshooter is a term commonly used to describe a group of leafhoppers in the family Cicadellidae. There have been several explanations for the use of this term. Riley and Howard (1893) first used 'sharpshooter' to describe the feeding damage of the glassy-winged sharpshooter, Homalodisca coagulata (Say), on cotton. This damage was caused by the piercing-sucking mouthparts of $H$. coagulata that appeared to be caused by a 'minute bullet.' They also reported 'rapid and forcible ejection of minute drops of fluid' as another explanation for the use of this term. The term sharpshooter is also attributed to the hiding behavior of these insects when alarmed. Disturbed sharpshooters will slip quickly behind branches and stems to avoid predators, an action not unlike the behavior of army sharpshooter riflemen who would hide behind the trunks of trees to avoid detection by the opposition as they passed by their position.

\section{Description aqnd Systematics}

Sharpshooters are leafhoppers in the tribes Proconiini and Cicadellini within the family Cicadellidae in the suborder Auchenorrhyncha of the Hemiptera. Worldwide, there are nearly 20,000 described species, making the Cicadellidae the 10th largest insect family. Presently, there are 300 genera within the two tribes. Because leafhopper diversity is directly related to plant diversity, many more new species will be undoubtedly be described as entomologists continue to explore pristine tropical regions.

Like all true bugs, sharpshooters have piercing-sucking mouthparts, which they use to tap into and feed upon xylem or phloem (sap) tissue of plants. Most leafhoppers have cryptic coloration (camouflage) and are often brown, green, or yellow which enables them to blend into their surroundings. Sharpshooters are expert jumpers with powerful hind legs lined with a row of distinct spines on the tibia. The adults have two pairs of wings and are strong flyers. The nymphs of sharpshooters are wingless but are capable of powerful leaps to search for food and

1. This document is EENY-334, one of a series of Featured Creatures from the Entomology and Nematology Department, Florida Cooperative Extension Service, Institute of Food and Agricultural Sciences, University of Florida. Published: October 2004. This document is also available on Featured Creatures Website at http://creatures.ifas.ufl.edu. Please visit the EDIS Website at http://edis.ifas.ufl.edu. Additional information on these organisms, including many color photographs, is available at the Entomology and Nematology Department website at http://entnemdept.ifas.ufl.edu/.

2. Chris Tipping and Russell F. Mizell, III, Department of Entomology and Nematology, University of Florida, Quincy, FL.

The Institute of Food and Agricultural Sciences (IFAS) is an Equal Opportunity Institution authorized to provide research, educational information and other services only to individuals and institutions that function with non-discrimination with respect to race, creed, color, religion, age, disability, sex, sexual orientation, marital status, national origin, political opinions or affiliations. U.S. Department of Agriculture, Cooperative Extension Service, University of Florida, IFAS, Florida A. \& M. University Cooperative Extension Program, and Boards of County Commissioners Cooperating. Larry Arrington, Dean 
to avoid predators. Sharpshooters have large eyes for excellent visual acuity to avoid detection and capture by potential predators. Additionally, they can detect the reflectance spectrum of several colors, with hues of yellow being the most attractive (Tipping et al. 2004).

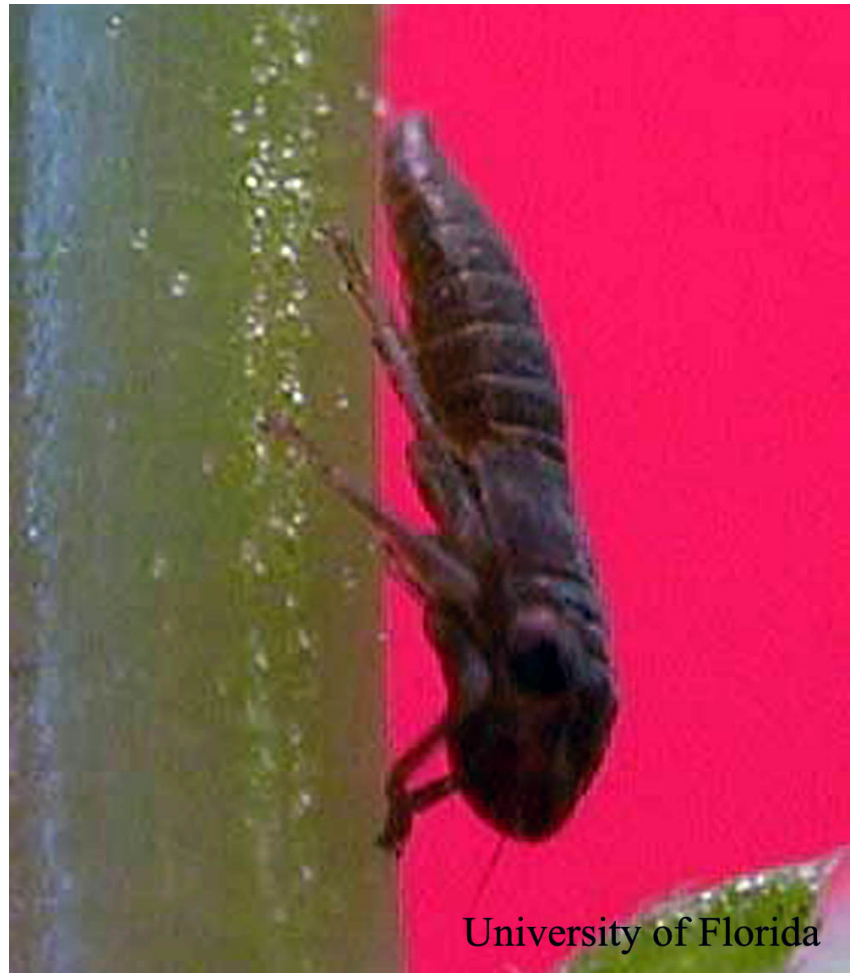

Figure 1. Newly emerged (neonate) glassywinged sharpshooter, Homalodisca coagulata (Say). Credits: Chris Tipping, University of Florida

Sharpshooters are among the largest of leafhoppers found in North America with several species nearly $30 \mathrm{~mm}$ in length. Some of the sharpshooters commonly found in Florida and throughout the southeastern U.S. are represented by the genera Cuerna, Homalodisca, Oncometopia and Paraulacizes (Turner and Pollard 1959).

\section{Life History}

Sharpshooters develop through a gradual metamorphosis. Females insert their eggs into plant tissue, usually leaves, with a sharp knifelike structure called an ovipositor (a structure that deposits eggs). Several species of sharpshooters produce a white chalky material known as brochosomes that is placed on the wing covers. After the eggs have been deposited into the plant, females then scrape this material to 'powder' the area (Rakitov 2004). There

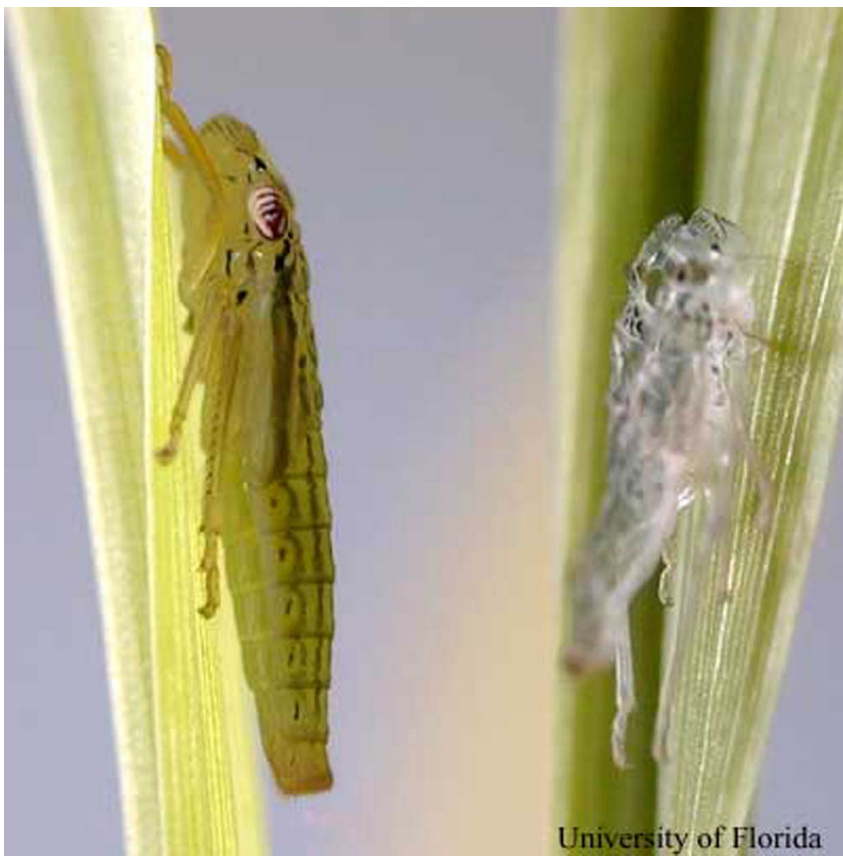

Figure 2. Newly eclosed (moulted) fifth instar nymph of Homalodisca insolita (Walker), a sharpshooter. Note the old exoskeleton (outer skin) to the right of the nymph. Credits: Chris Tipping, University of Florida

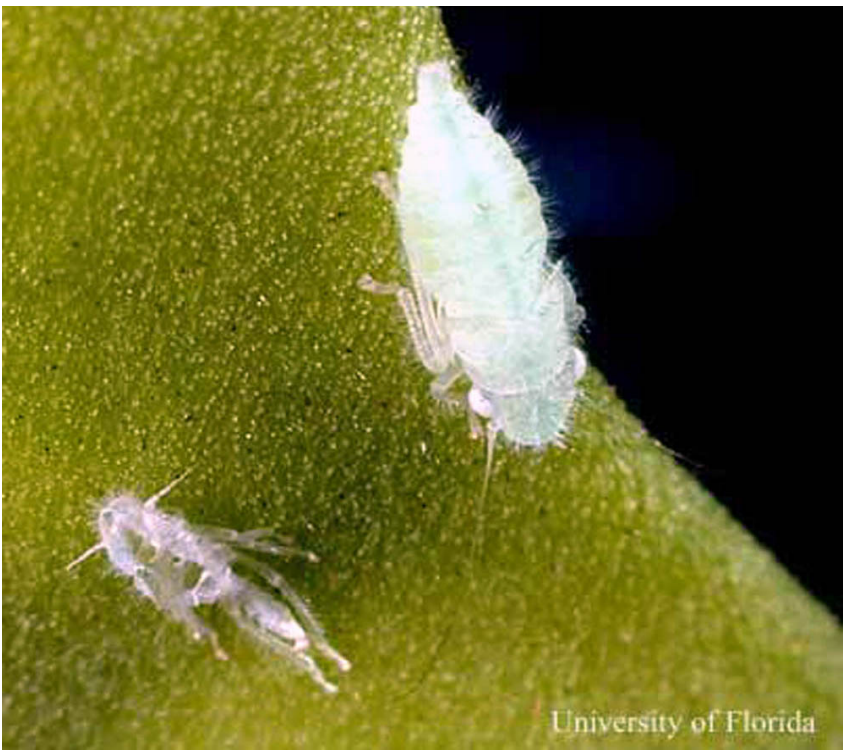

Figure 3. Newly eclosed (moulted) fourth instar of Paraulacizes irrorata Young, a sharpshooter. Note the old exoskeleton (outer skin) located lower left of the nymph. Credits: Chris Tipping, University of Florida

are five nymphal instars that are morphologically similar but increase in size with each stage. The adult stage initially emerges with small wings that require a few hours to fully expand and harden. The number of generations varies between sharpshooter species but is usually one to two per year. 


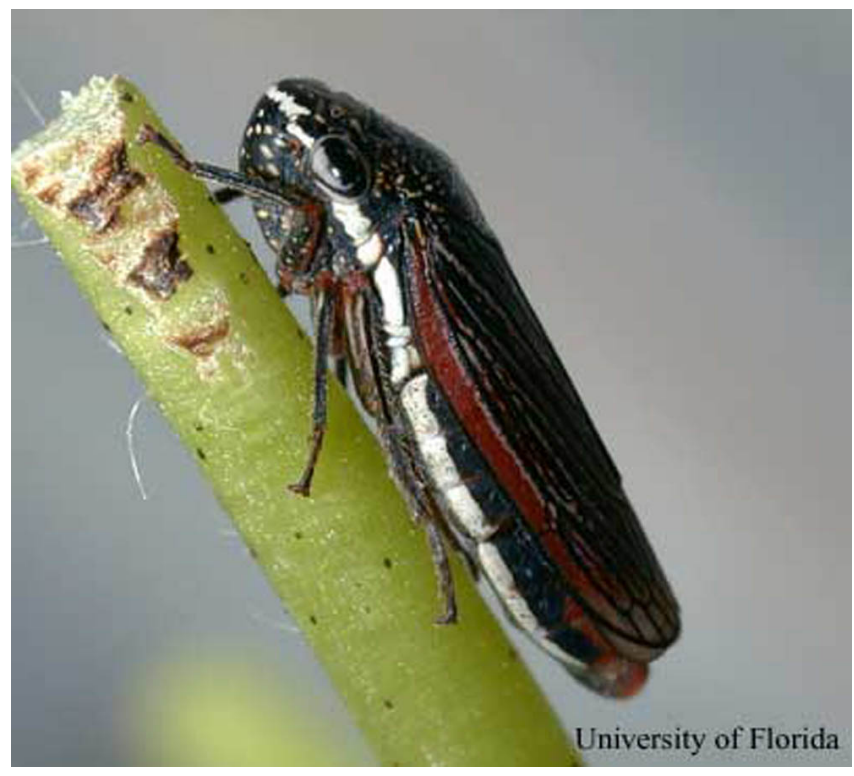

Figure 4. An adult Cuerna costalis (Fabricius), a sharpshooter. Credits: Chris Tipping, University of Florida

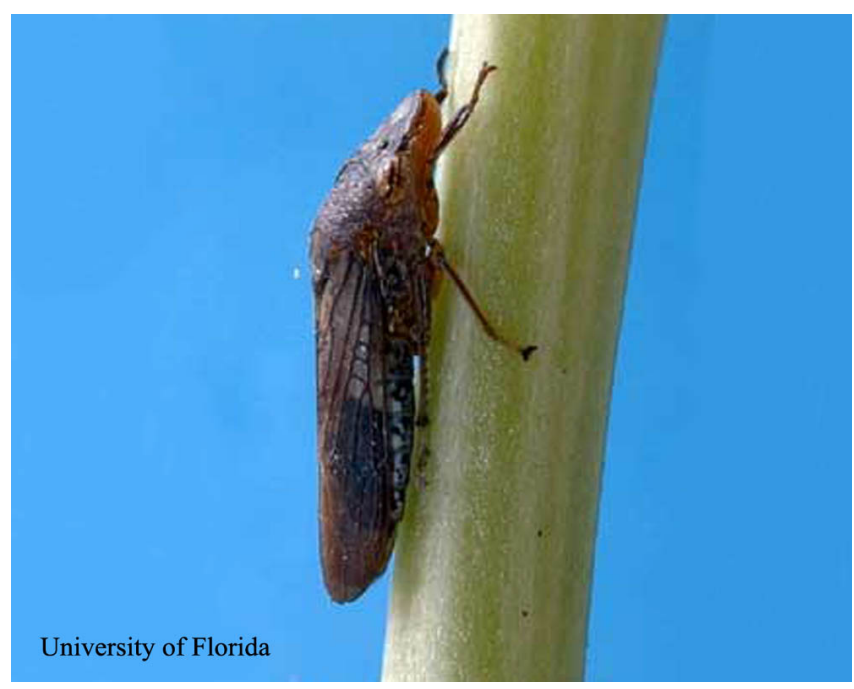

Figure 5. An adult Homalodisca coagulata (Say), the glassy-winged sharpshooter. Credits: Chris Tipping, University of Florida

Video of female $H$. coagulata ovipositing http://creatures.ifas.ufl.edu/fruit/sharpshooters/ H_coagulata_oviposition.htm

Video of female $H$. coagulata depositing brochosomes http://creatures.ifas.ufl.edu/fruit/ sharpshooters/ H_coagulata_brochosomes2.htm

\section{Diet}

The diet of the majority of sharpshooters consists exclusively of nutrient-poor xylem fluid from a great variety of plant species (Andersen et al. 1989). This fluid is comprised of over $95 \%$ water with small

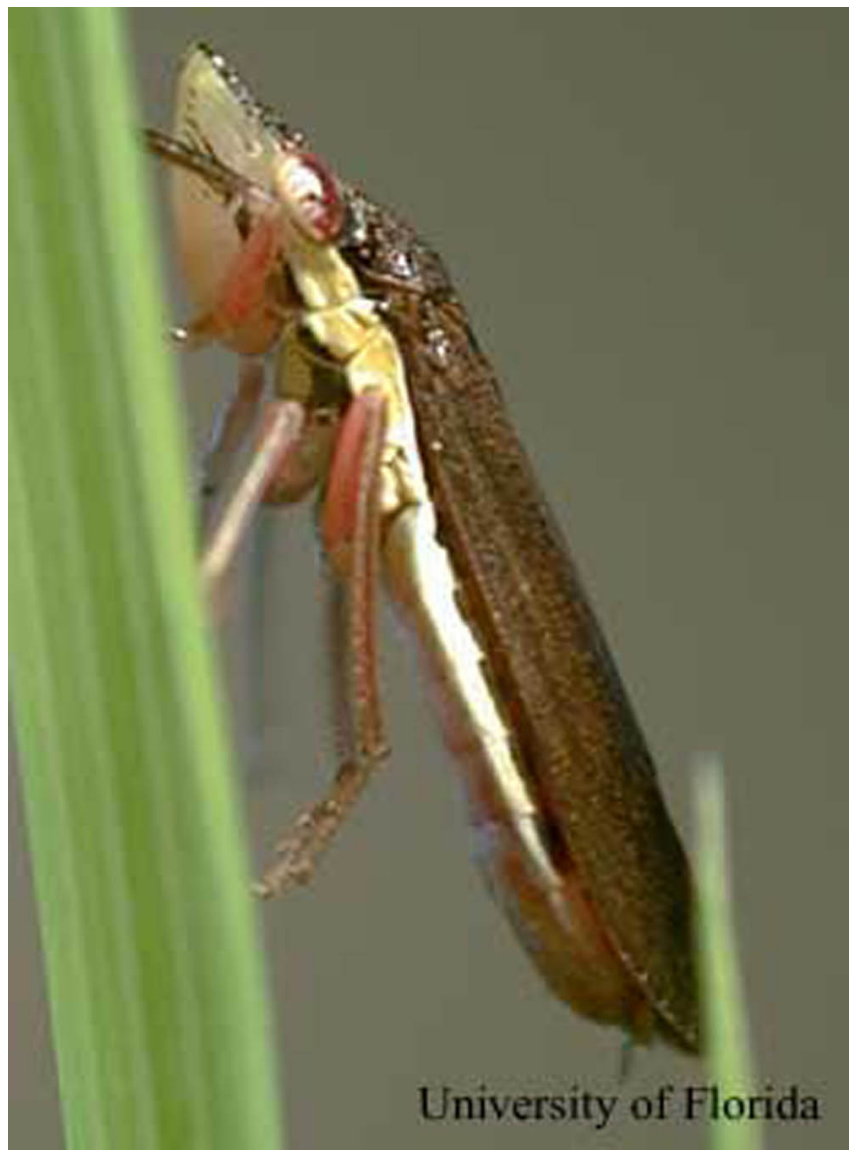

Figure 6. An adult Homalodisca insolita (Walker), a sharpshooter. Credits: Chris Tipping, University of Florida

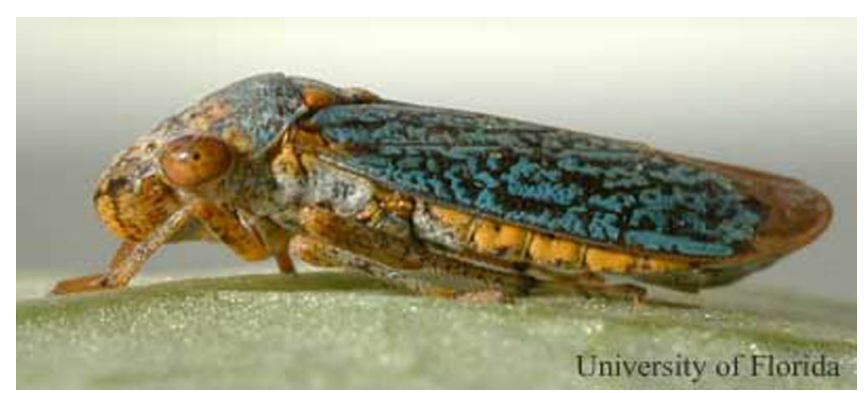

Figure 7. An adult Oncometopia nigricans (Walker), a sharpshooter. Credits: Chris Tipping, University of Florida

amounts of organic and inorganic molecules. Amino acids such as glutamine, arginine and asparagine, as well as organic acids such as citric, malic and oxalic acids are often present but occur in concentrations that are magnitudes lower than the nutrients found in other plant tissues. Because xylem fluid is under a negative pressure, leafhoppers must extract it with a cibarium pump (sucking apparatus) that is powered by large dilator muscles that have their origins in the bulging front region of the head. 


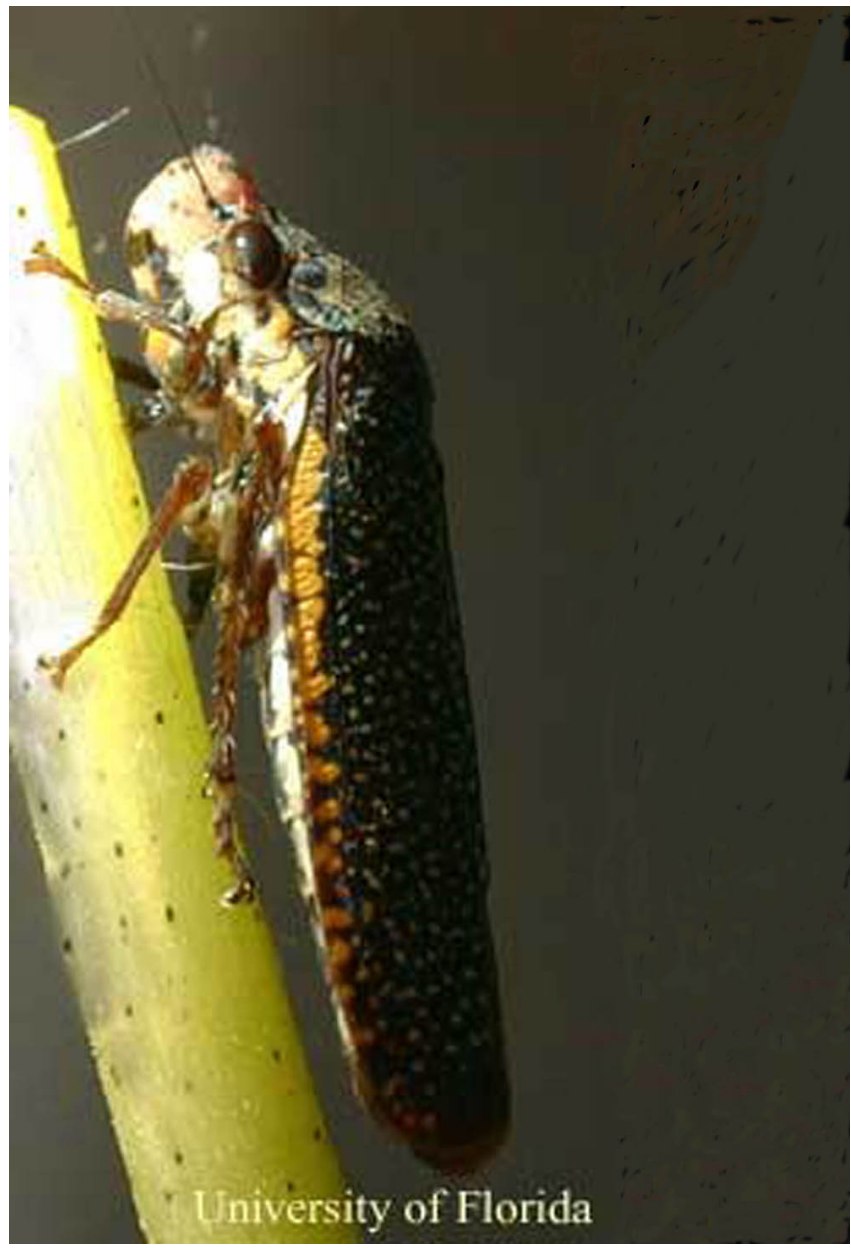

Figure 8. An adult Paraulacizes irrorata Young, a sharpshooter. Credits: Chris Tipping, University of Florida

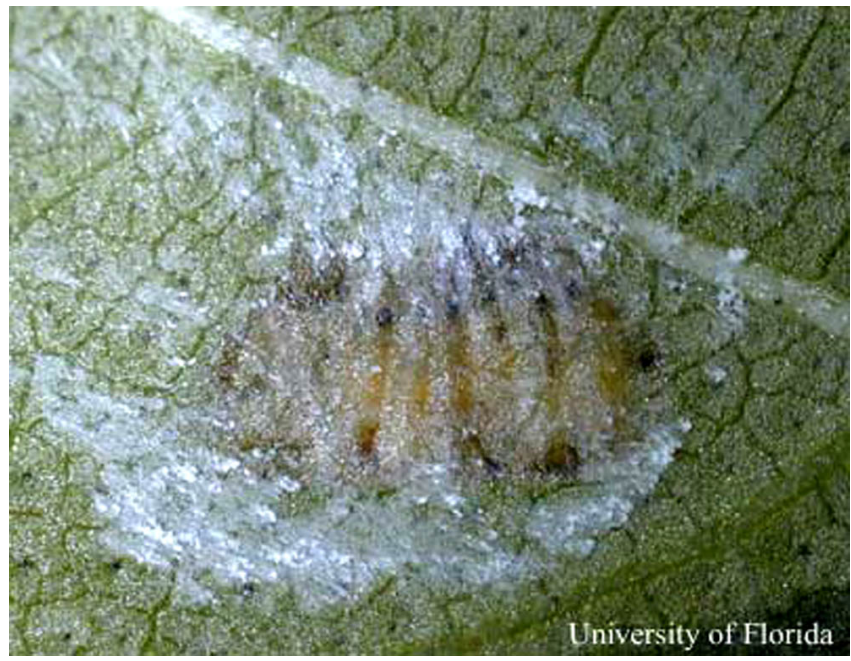

Figure 9. Egg mass of Homalodisca coagulata (Say), the glassy-winged sharpshooter, inserted into a cotton leaf with chalky white brochosomes present. Credits: Chris Tipping, University of Florida

To successfully develop and reproduce by feeding solely on nutritionally poor xylem fluid,

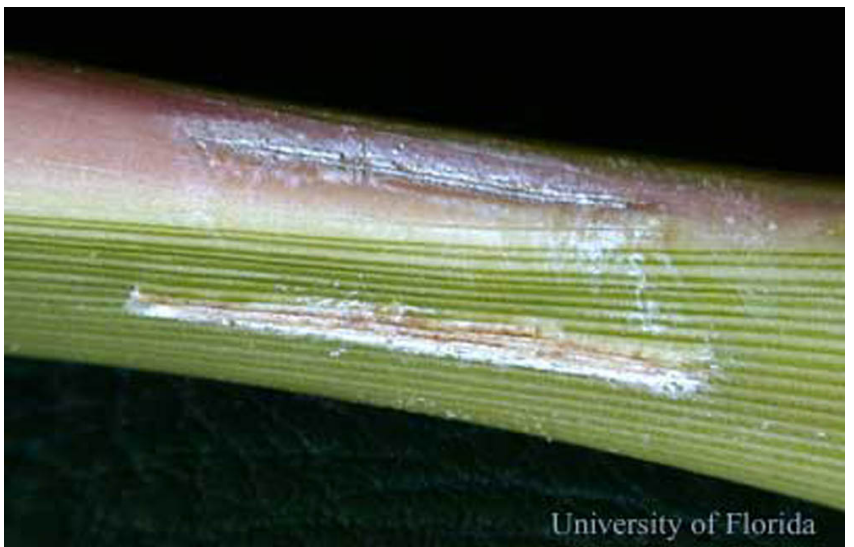

Figure 10. Two egg masses of Homalodisca insolita (Walker), a sharpshooter, inserted into Johnson grass, Sorghum halepense (Linnaeus). The egg mass is covered with brochosomes. Credits: Chris Tipping, University of Florida

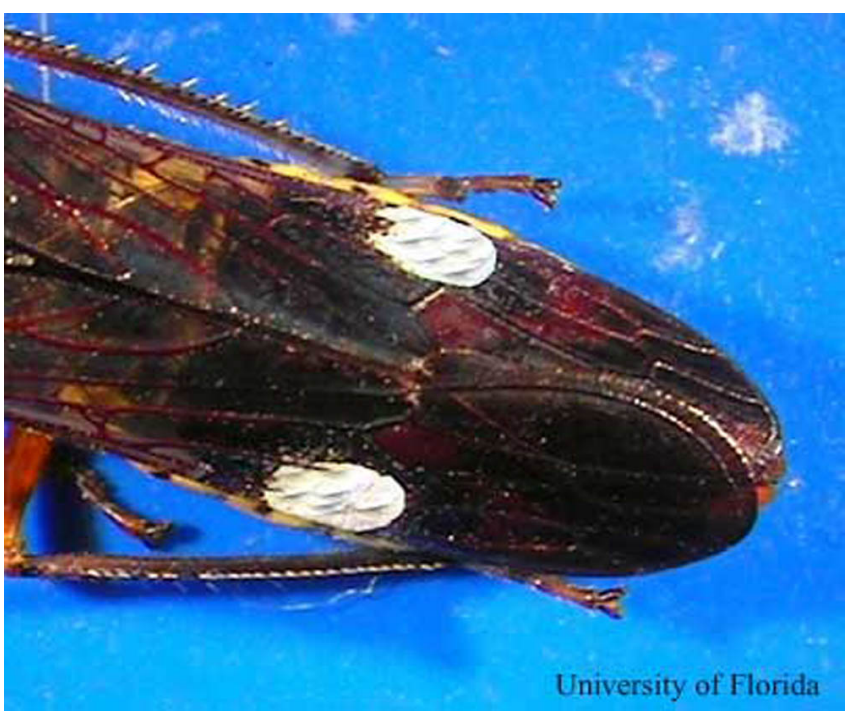

Figure 11. Forewings of Homalodisca coagulata (Say), the glassy-winged sharpshooter, with two patches of brochosomes. This material will be scraped onto an egg mass with the hind legs in a process known as 'powdering'. Credits: Chris Tipping, University of Florida

sharpshooters have high consumption rates coupled with an efficient digestive tract that features a re-circulating loop called a filter chamber. They are extremely efficient at assimilating what they have ingested and their waste is $99 \%$ water with small amounts of ammonia. Sharpshooters have been recorded to consume, process, and excrete $17 \mathrm{ml}$ per day (Tipping unpublished data). That is the equivalent of a person drinking nearly 400 gallons of water! The filter chamber allows for greater efficiency in absorbing nutrients from the dilute xylem fluid. 


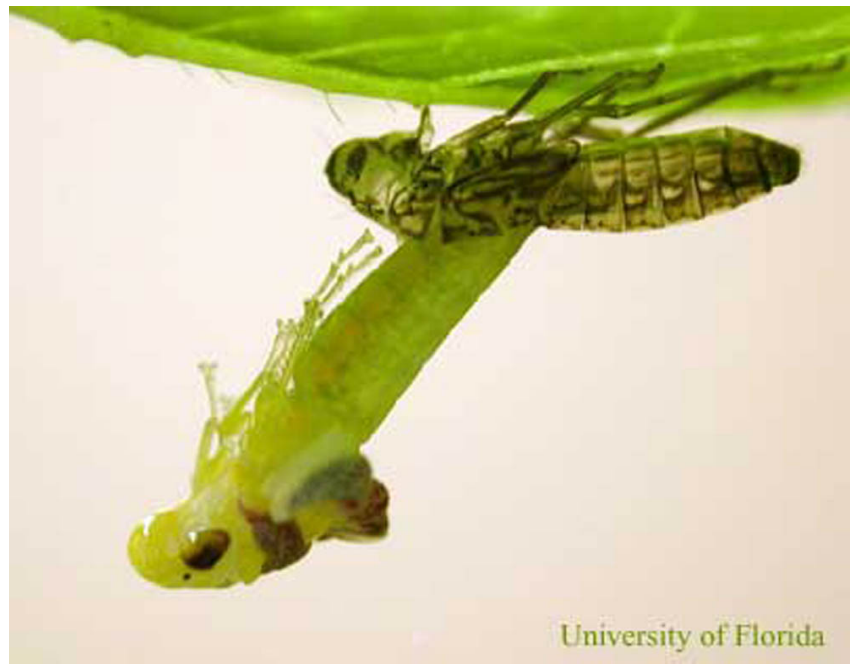

Figure 12. An adult Oncometopia nigricans (Walker), a sharpshooter, eclosing from the skin of the last nymphal stage. The wings are very small and have not expanded. Credits: Chris Tipping, University of Florida

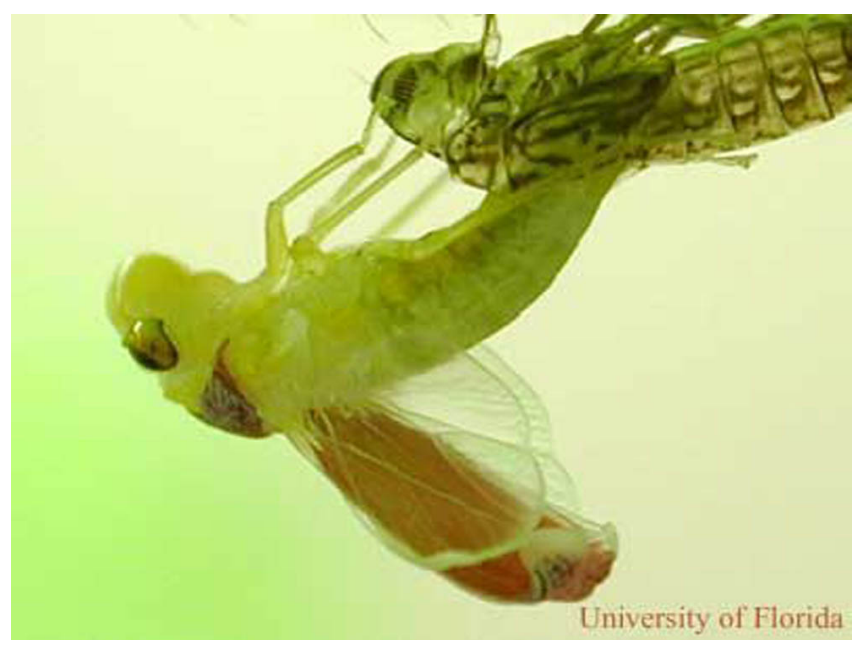

Figure 13. An adult Oncometopia nigricans (Walker), a sharpshooter, eclosing from the skin of the last nymphal stage. At this time, the wings are slowly beginning to expand. Credits: Chris Tipping, University of Florida

Video of $O$. nigricans excreting http://creatures. ifas.ufl.edu/fruit/sharpshooters/O_nigricans_ excreting.htm

In addition, the chemical composition of xylem fluid varies widely between plant species as well as within a single plant over the course of the season. Sharpshooters tend to find and congregate on certain plants during different times of the season to maximize nutrient consumption (Mizell and French 1987). As the nymphs and adults disperse to find adequate nutrients for development, maintenance, and reproduction, they determine host suitability by tasting.

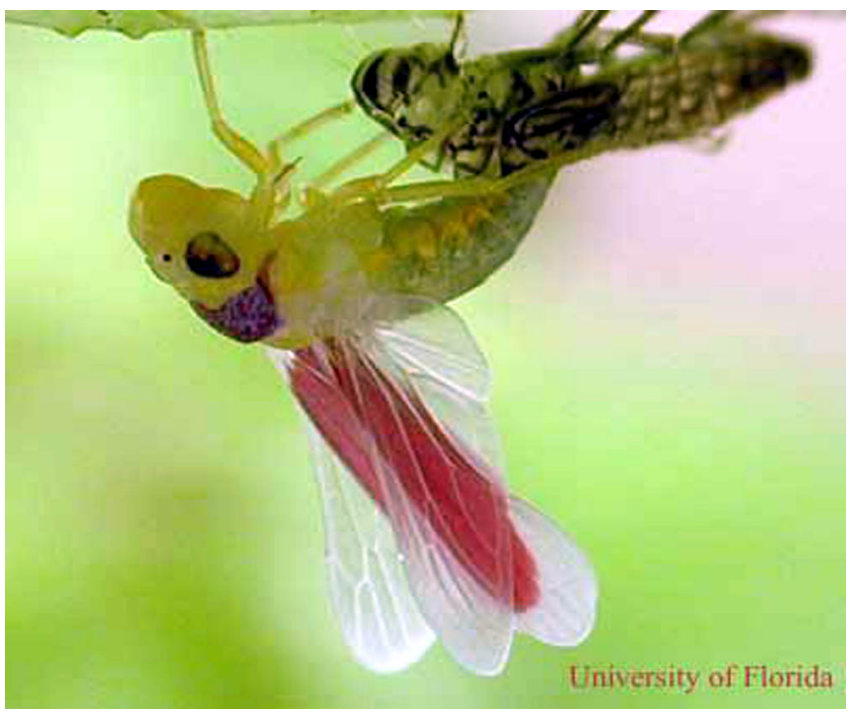

Figure 14. An adult Oncometopia nigricans (Walker), a sharpshooter, eclosing from the skin of the last nymphal stage. The wings are nearly full size. Credits: Chris Tipping, University of Florida

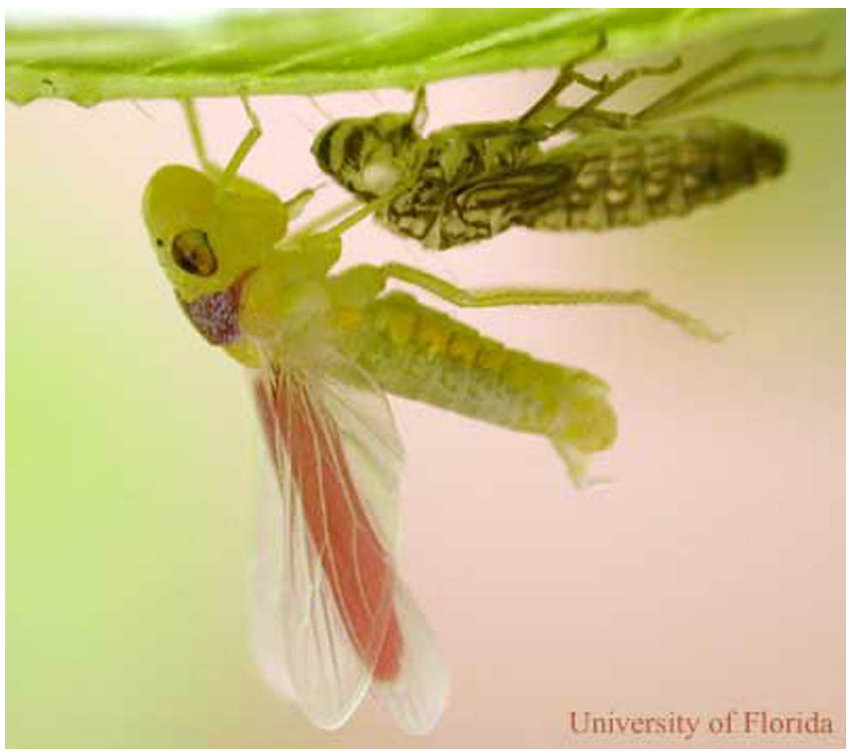

Figure 15. An adult Oncometopia nigricans (Walker), a sharpshooter, completely eclosed from the skin of the last nymphal stage. The wings are fully expanded and beginning to harden. Credits: Chris Tipping, University of Florida

\section{Economic Importance}

Because sharpshooters disperse relatively long distances as both nymphs and adults in their search for adequate nutrition required for development, maintenance, and reproduction, they feed on a great variety of plants. Sharpshooters can cause physical damage to plants by the insertion of their mouthparts or by robbing the plant of important nutrients. More 


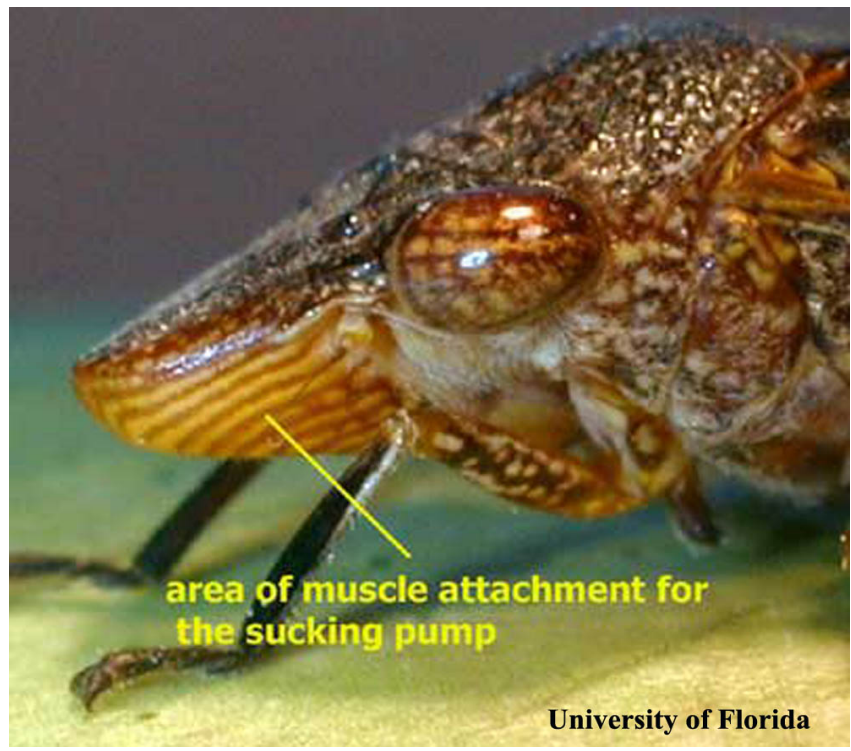

Figure 16. Large muscles in the head of Homalodisca coagulata (Say), the glassy-winged sharpshooter, are essential to power the cibarium pump because xylem fluid is under negative pressure. Credits: Chris Tipping, University of Florida

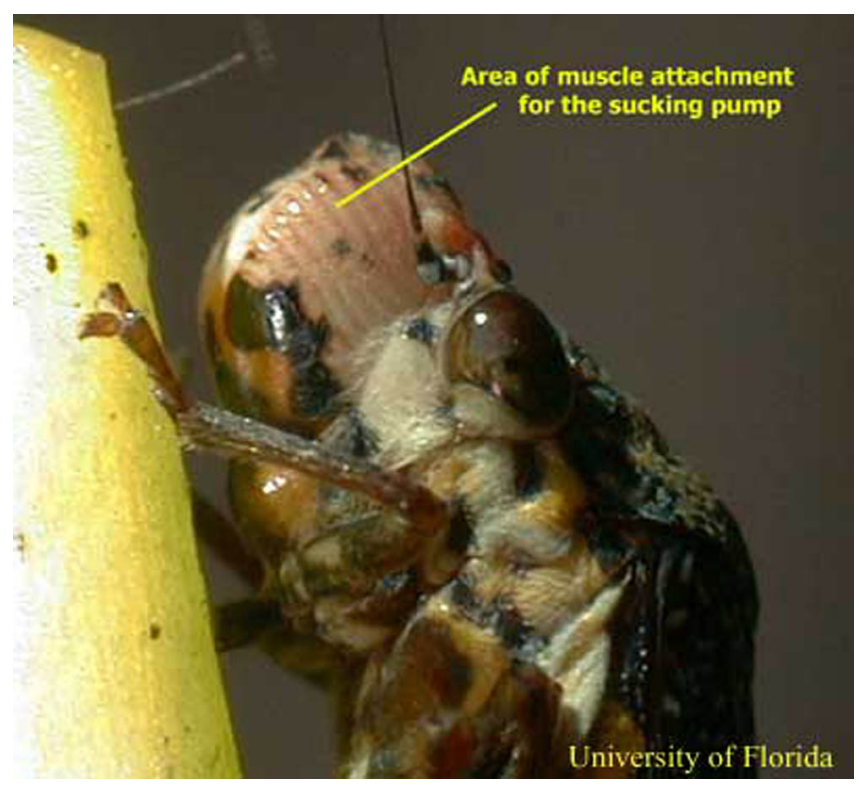

Figure 17. All xylem-feeding sharpshooters have enlarged heads that are full of dilator muscles; including this species, Paraulacizes irrorata Young. Credits: Chris Tipping, University of Florida

importantly however, is their ability to vector (transmit) infectious pathogens from plant to plant. Some of these pathogens include viruses, bacteria, and other microorganisms (McClure et al. 1982, Purcell and Suslow 1984). One of the most important disease organisms vectored by sharpshooters is the bacterium Xylella fastidiosa Wells et al. Xylella is the causative agent for a variety of economically important diseases including phony peach, plum leaf scald, almond leaf scorch, citrus variegated chlorosis (in Brazil) and Pierce's disease of grape (Wells et al. 1987, Mizell et al. 2003). The bacterium blocks the water-conducting xylem tissue causing scorch symptoms in diseased plants. Sharpshooters can acquire the bacterium after they feed on an infected plant. The bacterium can survive and colonize the inner linings of the mouthparts (Timmer et al. 1983). Once they have acquired Xylella, adult sharpshooters can vector it for the remainder of their lives. However, the nymphs lose the bacteria when they moult (shed their skin) the inner linings of the mouthparts but can reacquire the pathogen by feeding on an infected plant.

\section{Natural Enemies}

The natural enemies of sharpshooters include predatory insects such as mantids and dragonflies. Free living and snare building spiders also capture and eat sharpshooters. In Florida, anoles have been observed eating sharpshooters. Small parasitic wasps in the genus Gonatocerus are important natural enemies of sharpshooters because they attack the egg stage of several species (Lopez et al. 2004). The larvae of these minute wasps develop inside the eggs of the sharpshooter, and kill the developing embryo.

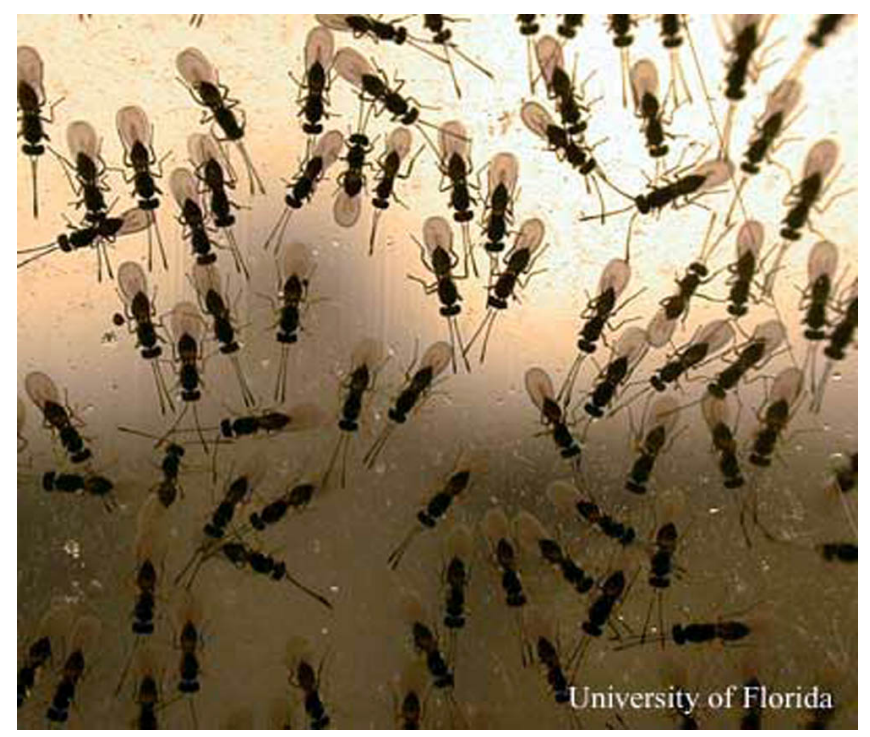

Figure 19. Parasitic wasps in the genus Gonatocerus are important natural enemies of several species of sharpshooters. Credits: Chris Tipping, University of Florida 


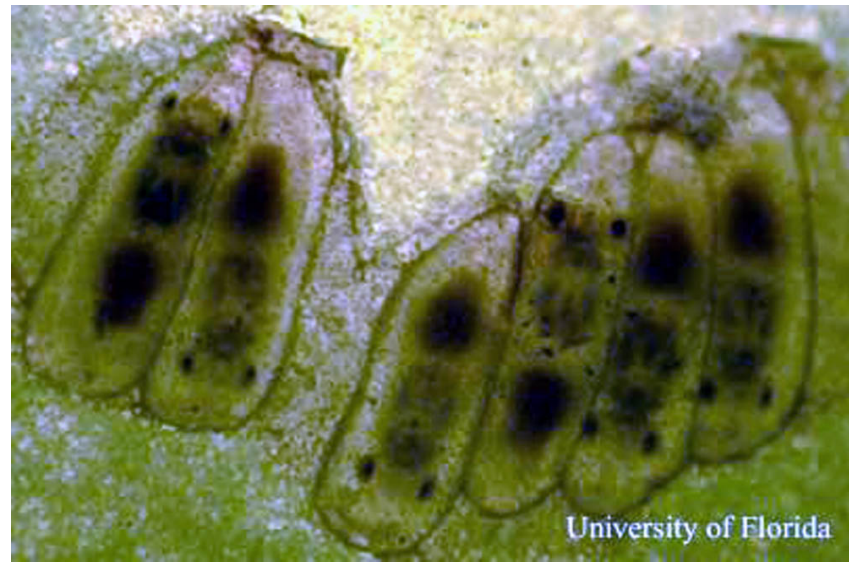

Figure 20. This egg mass has been successfully parasitized by Gonatocerus wasps. Each egg of Homalodisca coagulata (Say), the glassywinged sharpshooter, now has single Gonatocerus pupae inside it, which will soon eclose to an adult wasp. Credits: Chris Tipping, University of Florida

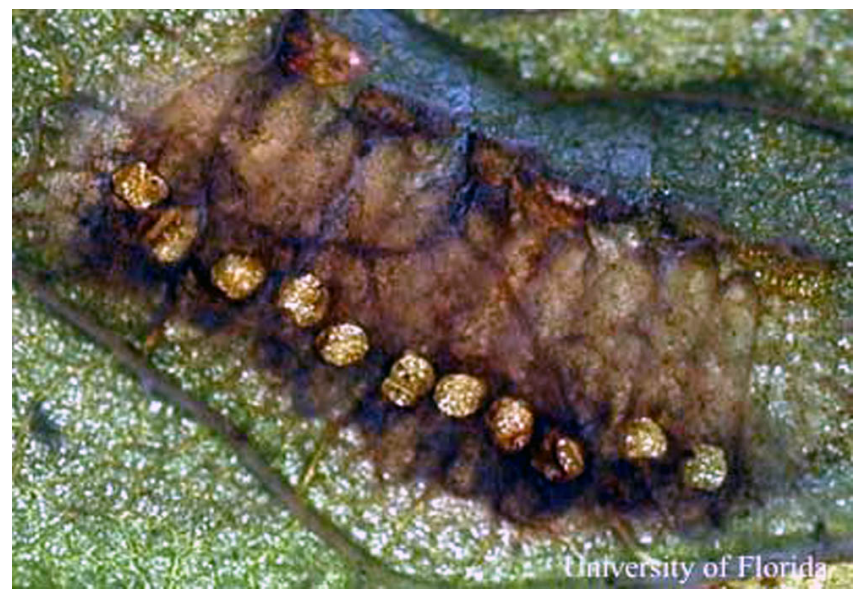

Figure 21. A single wasp (Gonatocerus sp.) emerged from each hole in the egg mass of Homalodisca coagulata (Say), the glassy-winged sharpshooter. The adult wasps chew a small circle in the eggshell of the host as well as the leaf to escape. Credits: Chris Tipping, University of Florida

In North Florida, several species of fungal pathogens reach epizootic levels in two species of sharpshooters, Homalodisca coagulata and Oncometopia nigricans. A new species of the genus Hirsutella has been found to be the principle pathogen (Boucias and Mizell unpublished). During cool, wet conditions, many sharpshooters can be found mycosed (attacked by fungi) and mummified in the field.

Strepsipterans, or twisted-wing parasites, are an unusual group of insects that parasitize a variety of insects including sharpshooters. Strepsipterans have

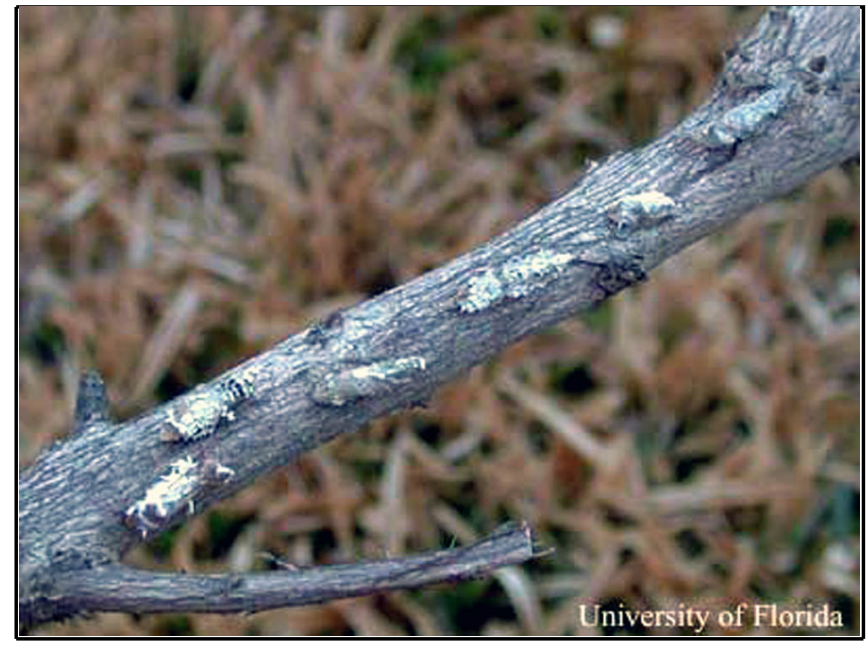

Figure 22. During cool, wet summers incidence of fungal epizootics rapidly increase in populations of Homalodisca coagulata (Say), the glassy-winged sharphooter. Credits: Chris Tipping, University of Florida

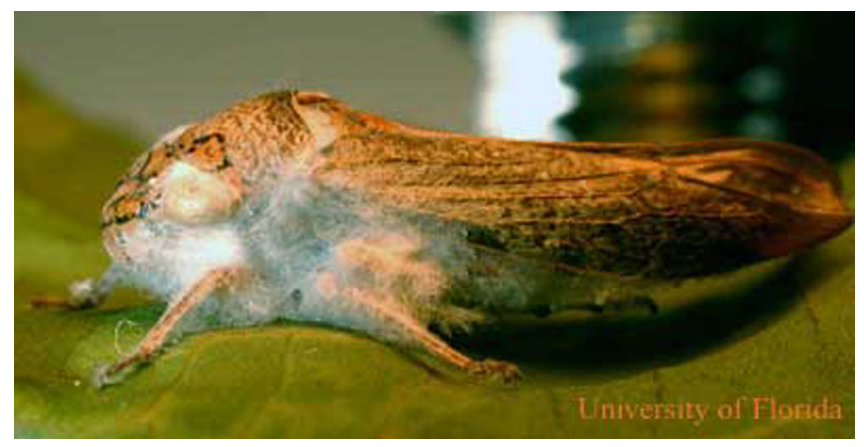

Figure 23. Sharpshooters, in this case Oncometopia nigricans (Walker), attacked by fungi are often covered with a fine coating of mycelia (white filaments). Credits: Chris Tipping, University of Florida

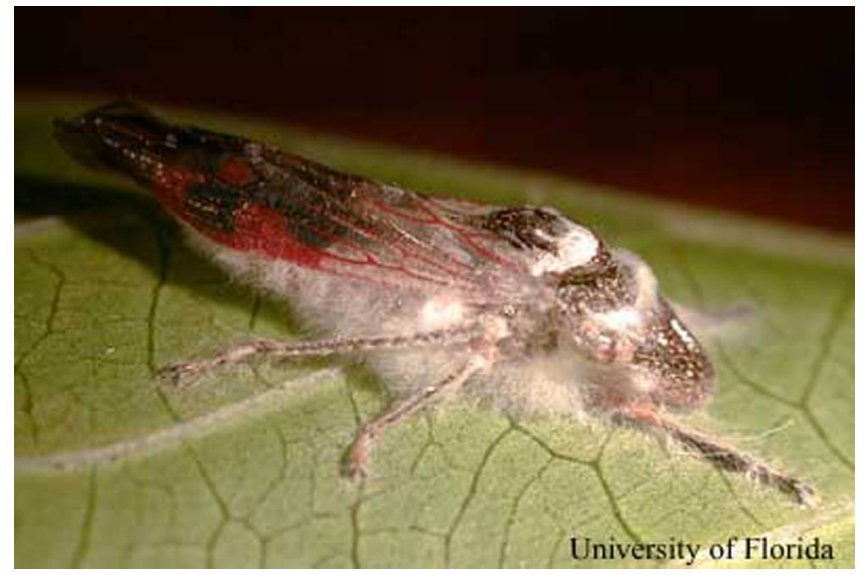

Figure 24. The presence of mycelia (white filaments) growing out of a dead glassy-winged sharpshooter, Homalodisca coagulata (Say), are symptomatic of mycosis (attack by fungus) by Hirsutella. Credits: Chris Tipping, University of Florida 
an unusual life cycle with adult females remaining inside the host but protruding a structure called a cephalathorax. Males emerge from pupal cases that also protrude from the host and seek out mature females for mating. The eggs remain within the body of the female until they eclose. The larvae are called triungulins (walking mobile stage) and escape the bodies of both the female and the host. After the triungulins enter a new host they lose their legs and appear maggot-like. Oncometopia nigricans is often stylopized (attacked by a strepsipteran) by an unidentified species of Halictophagidae. These parasites do not kill the sharpshooter host, however they have been reported to reduce the fecundity of infested females. Generally, a single strepsipteran is found within a host, although; on rare occasions, more than one may be present in a single host.

\section{Selected References}

Andersen PC, Brodbeck BV, Mizell III RF. 1989. Metabolism of amino acids, organic acids and sugars extracted from the xylem fluid of four host plants by Homalodisca coagulata. Entomologia Experimentalis et Applicata 50: 149-159.

Lopez R, Mizell III RF, Andersen PC, Brodbeck BV. 2004. Overwintering biology, food supplementation and parasitism of eggs of Homalodisca coagulata (Say) (Homoptera: Cicadellidae) by Gonatocerus ashmeadi Girault and Gonatocerus morilli (Howard) (Hymenoptera: Mymaridae). Journal of Entomological Science 39: 214-222.

McClure MS, Andreadis TG, Levy GH. 1982. Manipulating orchard ground cover to reduce invasion by leafhopper vectors of peach $\mathrm{X}$-disease. Journal of Economic Entomology 75: 64-68.

Mizell III RF, French WJ. 1987. Leafhopper vectors of phony peach disease: Feeding site preference and survival on infected and uninfected peach, and seasonal response to selected host plants. Journal of Entomological Science 22: 11-22.

Mizell III RF, Andersen PC, Tipping C, Brodbeck BV. (2003). Xylella fastidiosa diseases and their leafhopper vectors. EDIS. http://edis.ifas.ufl.edu/IN174 (12 October 2004).
Purcell AH, Suslow KG. 1984 Surveys of leafhoppers (Homoptera: Cicadellidae) and pear psylla (Homoptera: Psyllidae) in pear and peach orchards and the spread of peach yellow leaf roll disease. Journal of Economic Entomology 77: 1489-1494.

Timmer LW, Brlansky RH, Lee RF, Raju BC. 1983. A fastidious xylem-limited bacterium infecting ragweed. Phytopathology 73: 975-979.

Rakitov RA. 2004. Powdering of egg nests with brochosomes and related sexual dimorphism in leafhoppers (Hemiptera: Cicadellidae). Zoological Journal of the Linnaean Society 140: 353-381.

Riley CV, Howard LO. 1893. The glassy-winged sharpshooter. Insect Life 5: 150-154.

Tipping C, Mizell III RF, Andersen PC. 2004. Dispersal adaptations of immature stages of three species of leafhopper (Hemiptera: Auchenorrhyncha: Cicadellidae). Florida Entomologist 87: 372-379.

Turner WF, Pollard HN. 1959. Life histories and behaviors of five insect vectors of phony peach disease. USDA Technical Bulletin 1188. 28pgs.

Wells JM, Raju BC, Hung HY, Weisburg WG, Paul LM, Brenner DJ. 1987. Xylella fastidiosa gen. nov., sp. nov: gram-negative, xylem-limited, fastidious plant bacteria related to Xanthomonas spp. International Journal of Systematic Bacterology 37: 136-143 